${ }^{23}$ Fitzhardinge PM, Steven EM. The small-for-date infant: neurologica and intellectual sequelae. Pediatrics 1972;50:50-7.

24 Neligan GA, Kolvin I, Scott DM, Garside RF. Born too soon, born too small. Clinics in developmental medicine. No 61. London: Spastics International Medical Publications, Heinemann, 1976.

${ }^{25}$ Redman CWG, Beilin LJ, Bonnar J, Ounsted MK. A trial of antihypertensive treatment in pregnancy: fetal outcome. Lancet 1976;ii:753-6.

${ }^{26}$ Mutch LMM, Moar VA, Ounsted MK, Redman CWG. Hypertension during pregnancy with and without specific hypotensive treatment. i, Perinatal and postnatal factors. Early Hum Dev 1977;1:47-57.

27 Mutch LMM, Moar VA, Ounsted MK, Redman CWG. Hypertension during pregnancy with and without specific hypotensive treatment. $\mathrm{ii}$, The growth and development of the infant in the first year of life. Early Hum Dev 1977;1:59-67.

28 Ounsted MK, Moar VA, Good FJ, Redman CWG. Hypertension during pregnancy with and without specific treatment; the development of the children at the age of four years. Br $\mathcal{F}$ Obstet Gynaecol $1980 ; 87$ : 19-24.

${ }^{2 y}$ Cockburn J, Moar VA, Ounsted M, Redman CWG. Final report of study on hypertension during pregnancy: the effects of specific treatment on the growth and development of the children. Lancet $1982 ; \mathrm{i}$ : 647-9.

${ }^{30}$ Ounsted M, Cockburn J, Moar VA, Redman CWG. Maternal hypertension with superimposed pre-eclampsia: effects on child development at $7 \frac{1}{2}$ years. Br $\mathcal{F}$ Obstet Gynaecol 1983;90:644-9.

${ }^{31}$ Elliott CD, Murray DJ, Pearson LS. The British ability scales. Windsor: NFER Publishing Company Ltd, 1978.

32 Ounsted M, Moar V, Scott A. Perinatal morbidity and mortality in small-for-dates babies: the relative importance of some maternal factors. Early Hum Dev 1981 ;5:367-75.
${ }^{33}$ Scott A, Moar V, Ounsted M. The relative contributions of different maternal factors in small-for-gestational-age pregnancies. Eur $\mathcal{F}$ Obstet Gynaecol Reprod Biol 1981;12:157-65.

${ }^{34}$ Scott A, Moar V, Ounsted M. The relative contributions of different maternal factors in large-for-gestational-age pregnancies. Eı⿱r $\mathfrak{f}$ Obstet Gynaecol Reprod Biol 1982;13:269-77.

${ }^{35}$ Clarke ADB. Consistency and variability in the growth of human characteristics. Dev Med Child Neurol 1972;14:669-83.

${ }^{36}$ Stone FH. Birth order, intelligence and personality. Dev Med Child Neurol 1969;11:647-8.

37 Altus WD. Birth order and its sequelae. Science 1966;151:44-9.

38 Ounsted MK, Osborn ML, Sleigh G, Good FJ. A method of developmental assessment at four years and some associated findings. Early Hum Dev 1979;3:1-19.

${ }^{39}$ Ounsted M. Basics: size at birth and its effect on growth and development in the first year of life. In: Apley J, Ounsted C, eds. One child. London: Heinemann, 1982:84-121. (Clinics in Developmental Medicine, No 80.)

"0 Cockburn J, Ounsted M. The British ability scales: some differences between scores for Oxfordshire children and the standardization sample. Bulletin of the British Psychological Society 1983;36:83-4.

"1 Ounsted M, Moar VA, Scott A. Small for dates babies at the age of four years: health, handicap and developmental status. Early Hum Dev $1983 ; 8: 243-58$.

${ }^{12}$ Lilienfeld AM, Pasamanick B, Rogers M. Relationship between pregnancy experience and the development of certain neuro-psychiatric disorders in childhood. Am $\mathcal{F}$ Public Health 1955 ;45:637-43.

(Accepted 8 February 1984)

\section{Intravenous infusion of frusemide as treatment for ascites in malignant disease}

Continuous intravenous infusion of frusemide is useful in the management of renal failure and congestive cardiac failure. ${ }^{12} \mathrm{We}$ report on an adaptation of the technique for the rapid relief of patients with tense ascites associated with malignant disease.

\section{Case reports}

Case 1-A 66 year old woman with a serous papillary cystadenocarcinoma of the ovary without liver metastases presented with ascites that yielded positive results on cytological examination. Her condition failed to improve despite chemotherapy with cisplatin, chlorambucil, and cyclopenthiazide $0.75 \mathrm{mg}$ daily with potassium. Ascites continued to accummulate over three weeks, causing abdominal distension, dyspnoea, and weight gain of $5 \mathrm{~kg}$. She received spironolactone $100 \mathrm{mg}$ twice daily and frusemide $100 \mathrm{mg}$ given as an intravenous infusion over 24 hours in a total volume of $48 \mathrm{~m}$ physiological saline; diuresis of 2.841 occurred during the infusion, and she lost $7.7 \mathrm{~kg}$ in weight over the next 10 days.

Case 2-A 42 year old woman with carcinoma of the breast, liver metastases, and hypoalbuminaemia $(27 \mathrm{~g} / \mathrm{l}$, normal range $>30 \mathrm{~g} / \mathrm{l})$, did not respond to cytotoxic treatment and had tense ascites. The fluid had a protein content of $7 \mathrm{~g} / \mathrm{l}$ and yielded a negative result on cytological examination. After one week's treatment with frusemide $120 \mathrm{mg}$ daily by mouth and spironolactone $100 \mathrm{mg}$ daily there was no reduction of ascites. Frusemide $100 \mathrm{mg}$ in $500 \mathrm{ml}$ physiological saline was then infused intravenously over 24 hours and produced a diuresis of $2700 \mathrm{ml}$, weight loss of $1.8 \mathrm{~kg}$, a decrease in abdominal girth of $4.5 \mathrm{~cm}$, and complete resolution of the signs and symptoms of ascites. Ascites had not returned at the time of her death six weeks later.

Case 3-A 35 year old woman with hepatic metastases from carcinoma of the breast and deranged liver function (albumin concentration $25 \mathrm{~g} / \mathrm{l}$ ) presented with tense ascites. Frusemide $100 \mathrm{mg}$ daily and spironolactone $100 \mathrm{mg}$ daily gave no relief after 48 hours. Frusemide $100 \mathrm{mg}$ in $100 \mathrm{ml}$ physiological saline was infused intravenously by a syringe pump at a rate of $5 \mathrm{ml} / \mathrm{h}$. By 16 hours she had achieved a diuresis of $1060 \mathrm{ml}$, weight loss of $1.9 \mathrm{~kg}$, and a reduction in abdominal girth of $2 \mathrm{~cm}$. She was discharged taking frusemide $40 \mathrm{mg}$ and spironolactone $100 \mathrm{mg}$ daily by mouth; 19 days after the infusion her total reduction in girth was $11 \mathrm{~cm}$. The primary tumour did not respond subsequently to chemotherapy, but ascites did not recur.

Case 4-A 61 year old woman with carcinoma of the breast and hepatic metastases had ascites that yielded a negative result on cytological examination. Paracentesis of 31 had been followed by deterioration of liver function (albumin concentration $29 \mathrm{~g} / \mathrm{l}$ ). The ascites reaccummulated and was unresponsive to oral spironolactone $200 \mathrm{mg}$ and frusemide $80 \mathrm{mg}$ daily. Frusemide $100 \mathrm{mg}$ in $500 \mathrm{ml}$ physiological saline was infused intravenously over 24 hours and led to a diuresis of $1600 \mathrm{ml}$, weight loss of $1.4 \mathrm{~kg}$, and reduction in abdominal girth of $5.5 \mathrm{~cm}$. The infusion was repeated 48 hours later with complete clinical resolution of ascites.

\section{Comment}

These four patients with intra-abdominal malignancy sustained immediate relief of ascites after the intravenous infusion of frusemide. The major reductions in symptoms and girth measurements were associated with a fairly small diuresis, suggesting a redistribution of body fluids as well as an absolute loss. The presence or absence of hepatic dysfunction did not affect outcome. The procedure was well tolerated, and there were no appreciable electrolyte disturbances, probably because of the small dose of frusemide given in only a short time by this technique. ${ }^{3}$ It is more logical to minimise the volume of saline given by infusing more concentrated frusemide solutions with the aid of an electric pump, as was done in cases 1 and 3 . The procedure was free of the hazards of paracentesis and more effective than giving an oral diuretic. It offers a useful treatment for this distressing complication of malignant disease.

${ }^{1}$ Allison MFH, Kennedy AC. Diuretics in chronic renal disease: a study of high dosage frusemide. Clin Sci $1971 ; \mathbf{4 1}: 171-87$.

${ }^{2}$ Gray JMB, Henry DA, Lawson DH, Tilstone WJ. Continuous infusion of frusemide in refractory oedema. Br $\mathcal{F}$ Clin Pharmacol 1978;6:461P.

${ }^{3}$ Fogel MR, Sawhney VK, Neal A, Miller RG, Knauer CM, Gregory PB. Diuresis in the ascitic patient: a randomized controlled trial of three regimens. F Clin Gastroenterol 1981 ;3,suppl 1:73-80.

(Accepted 19 fanuary 1984)

Imperial Cancer Research Fund Breast Cancer Unit and Medical Oncology Clinic, Guy's Hospital, London SE1 9RT

STEPHANIE A AMIEL, MB, MRCP, registrar

ANN $M$ BLACKBURN, MD, MRCP, lecturer in medicine ROBERT D RUBENS, MD, MRCP, consultant physician

Correspondence to: Dr R D Rubens. 